\title{
Dual-stage sugar substitution in Tommy Atkins mango
}

\author{
Rafael A. B. de Medeiros ${ }^{1}$, Zilmar M. P. Barros², Carlos B. O. de Carvalho ${ }^{3}$, \\ Antonio C. D. Coêlho ${ }^{3}$, Maria I. S. Maciel ${ }^{4} \&$ Patricia M. Azoubel $^{3}$
} ${ }^{1}$ Universidade Federal de Pernambuco/Centro de Ciências da Saude/Departamento de Nutrição. Recife, PE. E-mail: rafaelmestrado2013@gmail.com -
ORCID: 0000-0002-9085-0345
${ }^{2}$ Universidade Federal de Pernambuco/Centro de Biociências/Departamento de Antibióticos. Recife, PE. E-mail: zizi.pimenta@gmail.com - ORCID:
0000-0003-3723-2019
${ }^{3}$ Universidade Federal de Pernambuco/Centro de Tecnologia e Geociências/Departamento de Engenharia Química. Recife, PE. E-mail:
carlos_bry@hotmail.com.br - ORCID: 0000-0001-6542-4670; coelho@ufpe.br - ORCID: 0000-0002-5875-8944; pazoubel@gmail.com
(Corresponding author) - ORCID: 0000-0001-9890-5294
${ }^{4}$ Universidade Federal Rural de Pernambuco/Programa de Pós graduação em Ciência e Tecnologia de Alimentos/Departamento de Ciências Domésticas.
Recife, PE. E-mail: m.inesdcd@gmail.com - ORCID: 0000-0002-8910-2833

\begin{abstract}
The dual-stage sugar substitution technique (D3S) was used to induce sugar replacement in mango. It involved two stages, in which high-calorie sugars were partially removed from the fruit samples in the first stage and, in the second one, low-calorie sugar was incorporated into the mango. Ultrasonic waves can be applied in one or both stages and their use was also evaluated in this study. Results showed that submitting samples to ultrasonic waves $(25 \mathrm{kHz})$ in both stages and their immersion in Stevia-based solution ( 250 or $500 \mathrm{~g} \mathrm{~kg}^{-1}$ ) in the second stage for 10, 20 and $30 \mathrm{~min}$ of processing gave higher water loss during the process, while greater solids gain could be achieved by applying ultrasound only in the first stage. Samples were also evaluated in terms of some quality parameters. The use of this technique resulted in samples with higher values of total phenolic content and changes in color parameters $\left(\mathrm{L}^{*}, \mathrm{a}^{\star}\right.$ and $\left.\mathrm{b}^{\star}\right)$. When samples were subjected to ultrasonic waves in both stages, a higher carotenoid retention was observed.
\end{abstract}

Key words: carotenoids, color, Mangifera indica, phenolics, preservation

\section{Substituição de açúcar em dois estágios na manga Tommy Atkins}

RESUMO: A técnica de substituição de açúcar em dois estágios (D3S) foi utilizada para induzir a troca de açúcares na manga. Esta técnica envolve dois estágios, nos quais os açúcares de alto teor calórico são parcialmente removidos das amostras de frutas no primeiro estágio e, no segundo, açúcar de baixa caloria é incorporado à manga. Ondas ultrassônicas podem ser aplicadas em um ou ambos estágios e seu uso também foi avaliado neste trabalho. Os resultados indicaram que submeter as amostras às ondas ultrassônicas (25 $\mathrm{kHz}$ ) nos dois estágios e sua imersão em solução a base Stevia ( $\left.250 \mathrm{ou} 500 \mathrm{~g} \mathrm{~kg}^{-1}\right)$ no segundo estágio por 10 , 20 e $30 \mathrm{~min}$ de processamento resultou em maiores perdas de água durante o processo, enquanto maiores valores de ganho de sólidos foram obtidos pela aplicação do ultrassom apenas no primeiro estágio. As amostras também foram avaliadas em relação a alguns parâmetros de qualidade. $O$ uso desta técnica resultou em amostras com maiores valores de fenólicos totais e em mudanças nos parâmetros de cor $\left(\mathrm{L}^{\star}, \mathrm{a}^{\star} \mathrm{e} \mathrm{b}^{\star}\right)$. Quando as amostras foram submetidas às ondas ultrassônicas em ambos estágios, uma maior retenção de carotenoides foi observada.

Palavras-chave: carotenoides, cor, Mangifera indica, fenólicos, preservação 


\section{INTRODUCTION}

Mango has limited storage life and is susceptible to chilling injury (Sogi et al., 2015). Therefore, some techniques are necessary to increase its preservation and storage period and to reduce the wastes from the harvest season ( $\mathrm{Pu} \& \mathrm{Sun}, 2016$ ).

Food demand has increased in the past years not only with respect to its quantity but also its quality, requiring changes in techniques for food processing (Pingret et al., 2013). Consumers are demanding for products based on natural and healthy appeal, with low content of sugar (Oliveira et al., 2012). Thus, low-calorie sweeteners with a potential to replace sugar have been investigated (Gasmalla et al., 2014).

Steviol glycoside is an attractive non-caloric sugar substitute for the food industry (Crammer \& Ikan, 1986). It has some advantages when compared to other sugars: its source is natural, stability at temperatures up to $200{ }^{\circ} \mathrm{C}$, acidstable, not fermentable (Kroyer, 2010), and acceptable sensory characteristics (Prakash et al., 2008). It finds extensive use in several countries to sweeten food products (Elkins, 1997). Garcia-Noguera et al. (2010) reported that it has a great potential to be used in dried fruit products and proposed a new technique called dual-stage sugar substitution (D3S). In the D3S first stage, caloric sugars are removed from the fruit, while in the second one a Stevia-derived sweetener is incorporated by the material. This technique was applied to Malay apples and strawberry (Garcia-Noguera et al., 2010; Oliveira et al., 2012), where the use of ultrasonic waves during the D3S process was reported to enhance mass transfer (sugar removal in the first stage and/or stevia incorporation in the second one).

This work studied the use of the D3S technique for the sugar substitution in mango by Stevia natural sweetener using ultrasonic pretreatments in osmotic solutions. The effect of ultrasound application during the D3S stages was determined. The samples were also evaluated for total phenolic and total carotenoids contents, and total color difference.

\section{Material and Methods}

The experiments were carried out at the Laboratory of Chemical Processes, Department of Chemical Engineering (DEQ), Federal University of Pernambuco (UFPE), in Recife, Pernambuco state, Brazil.

Tommy Atkins mangoes were purchased in a local market (Recife, Brazil), transported to the laboratory and stored at $4{ }^{\circ} \mathrm{C}$ until processing. Throughout the research, firm and healthy mangoes, without injuries of pathological, mechanical or physiological nature were used in the experiments. The fruits were washed in tap water, the peel was removed manually and the pulp was sliced $(3.0 \times 5.0 \times 0.5 \mathrm{~cm})$ using cutters designed for this purpose.

The average initial moisture content of mango was $0.864 \pm$ $0.002 \mathrm{~kg}$ water $\mathrm{kg}^{-1}$ fresh fruit, the soluble solids content was $14 \pm 0.3^{\circ} \mathrm{Brix}$, the reducing sugars content was $8.70 \pm 0.28 \%$, $\mathrm{pH}$ was $3.97 \pm 0.03$, acidity was $0.39 \pm 0.07 \%$ citric acid, and water activity was $0.97 \pm 0.12$.

The D3S process parameters and conditions (e.g. solution concentration, immersion time, ultrasound frequency) was based on Garcia-Noguera et al. (2010) and in preliminary tests. The experiments were performed in triplicate.

For the first stage, conical flasks with distilled water and two mango samples (near $10 \mathrm{~g}$ each batch) were placed in an ultrasonic bath (frequency of $25 \mathrm{kHz}$ ) (Unique, model USC$2850 \mathrm{~A}$, Brazil). The weight ratio between the fruit and the liquid medium was 1:4 (Azoubel et al., 2010). Experiments were performed at $30{ }^{\circ} \mathrm{C}$ with and without submitting fruit samples to ultrasonic waves.

After $30 \mathrm{~min}$, samples were removed from the solution, drained, blotted with absorbent paper and weighed. For the moisture content determination, the samples were placed in a drying oven at $105^{\circ} \mathrm{C}$ for $24 \mathrm{~h}$ (Tecnal, TE-395, Brazil). The water loss (WL) and solid gain (SG) were calculated according to Azoubel et al. (2010).

For the second stage, it was used three immersion times $(10,20$ and $30 \mathrm{~min})$, two Stevia solution concentrations (250 and $500 \mathrm{~g} \mathrm{~kg}^{-1}$ solution) and the samples were submitted (25 $\mathrm{kHz})$ or not $(0 \mathrm{kHz})$ to ultrasonic waves. Experiments were conducted as explained in the first stage. Stevia powder donated by Steviafarma (Brazil) was used as the natural sweetener.

Total carotenoids and total phenolic contents were determined according to Rodriguez-Amaya (1999) and Singleton et al. (1999), respectively.

The color parameters $\left(\mathrm{L}^{*}, \mathrm{a}^{\star}\right.$ and $\left.\mathrm{b}^{\star}\right)$ of mango were determined using a colorimeter (Minolta, CR400, Japan). The color change after processing (TCD) was determined according to Medeiros et al. (2016).

The quality analysis was carried out in triplicate.

Analysis of variance (ANOVA) of the results was performed to determine significant differences among samples. Means were compared by Tukey test at 0.05 probability level.

\section{Results AND Discussion}

The initial moisture content for mango was $0.864 \pm 0.002 \mathrm{~kg}$ water $\mathrm{kg}^{-1}$ fresh fruit. The final moisture content of processed samples varied and it was used to calculate the water loss and solid gain values.

During the first stage, water was incorporated into the fruit, while it lost solids to the water medium (Table 1). This was expected as the concentration gradient favored this behavior. Thus, the moisture content of the fruit became higher (increased by 2.67 and $4.69 \%$ for 0 and $25 \mathrm{kHz}$, respectively). A similar trend was reported by Azoubel et al. (2010), which obtained bananas with higher moisture content after the fruit pretreatment.

The first D3S stage had as objective the removal of highcalorie sugars, like glucose and fructose, and this sugar loss was considered equivalent to the loss of soluble solids (Oliveira

Table 1. Water loss (WL) and solid gain (SG) of mango after the first D3S stage

\begin{tabular}{cccc}
\hline $\begin{array}{c}\text { Ultrasonic } \\
\text { frequency } \\
\text { applied (kHz) }\end{array}$ & WL & SG & $\begin{array}{c}\text { Moisture } \\
\text { content }\end{array}$ \\
\cline { 2 - 4 } & \multicolumn{3}{|c}{} \\
\hline 0 & $-3.05 \pm 0.17$ & $-2.22 \pm 0.02$ & $88.75 \pm 0.25$ \\
25 & $-4.31 \pm 0.27$ & $-4.03 \pm 0.03$ & $90.49 \pm 0.71$ \\
\hline
\end{tabular}


et al., 2012). As negative values were obtained for SG, it was confirmed the loss of solids from the samples during this stage. The higher soluble solids loss obtained for mango was observed when it was submitted to ultrasonic waves.

The results for the mass transfer parameters evaluated in the second D3S stage are presented in Table 2. For water loss, it can be observed that when the solution concentration was higher, there was a significant increase $(\mathrm{p}<0.05)$ in water loss. It was not statistically significant only when mangoes were not submitted to ultrasonic waves in the first and second stages and the immersion time was $10 \mathrm{~min}$ in the second stage. Mendes et al. (2013) reported that increasing solution concentration promoted higher water loss due to an increase in the osmotic pressure. There is also a general trend when the samples were submitted to ultrasonic waves of a significant ( $95 \%$ confidence level) continuous increment of water loss when immersion time in Stevia solutions increased from 10 to $30 \mathrm{~min}$. The greatest water loss (11.61\%) was obtained when the fruit was submitted to ultrasound in the first and second stages and immersed in the higher Stevia solution concentration for $30 \mathrm{~min}$. Similar results were observed when this process was applied to strawberries (Garcia-Noguera et al., 2010) and in Malay apples (Oliveira et al., 2012). However, in the case of Malay apples, samples were immersed for a longer time (45 $\mathrm{min}$ ).

In a general way, solid gain values tended to significantly increase $(\mathrm{p}<0.05)$ as immersion time and solution concentration increased. As observed by Garcia-Noguera et al. (2010), when ultrasound was applied in both stages, the solids gains were slightly higher than those obtained when no ultrasonic waves were applied $(0 \mathrm{kHz})$ in the first stage. However, the D3S process resulting in higher sweetener gain $(3.56 \%)$ was obtained for mangoes submitted to ultrasonic waves in the first stage (sugar removal stage) followed by immersion in the $50 \mathrm{~g} \mathrm{~kg}^{-1}$ Stevia-based solution for $30 \mathrm{~min}$ without ultrasonic application. The same behavior was observed by GarciaNoguera et al. (2010) for strawberries. The authors reported that during the first stage the formation of micro-channels in the fruit tissue structure caused by the application of ultrasonic waves favored the Stevia incorporation in the second stage. The higher sweetener (Stevia) gain without the application of ultrasound in the second stage was attributed to the lower osmotic pressure of the Stevia-based solution and to the fact that ultrasound could cause soluble solids extraction from the fruit, reducing the entry of solids into the strawberry. Thus, the process could be performed without using ultrasound in the second stage in order to recuperate the mango initial sweetness.

The food industry is interested in technologies that can promote microorganism control in foods without changing its initial quality (nutritional and sensory characteristics). Studies about the use of ultrasound and its interference on the quality of fruit juices are common. However, for a potential use by the food industry, an evaluation of products submitted to new technologies is necessary (São José et al., 2014).

Table 3 shows the obtained values for the evaluated quality parameters before and after two processing conditions of the osmotic process. Those conditions were chosen based on higher values of mass transfer parameters (WL and SG) and were named D3S 1 (ultrasound in the first stage for $30 \mathrm{~min}$ followed by immersion of samples in a $500 \mathrm{~g} \mathrm{~kg}^{-1}$ Stevia-based solution for $30 \mathrm{~min}$ at $0 \mathrm{~Hz}$ ) and D3S 2 (ultrasound in the first stage for $30 \mathrm{~min}$ followed by the sample immersion in a $500 \mathrm{~g} \mathrm{~kg}^{-1}$ Stevia-based solution for $30 \mathrm{~min}$ at $25 \mathrm{~Hz}$ ), respectively.

Total phenolic content (TPC) for fresh and treated samples are significantly different $(\mathrm{p}<0.05)$ (Table 3 ). TPC was higher after the D3S process, but no significant difference between the two D3S treated mangoes was observed. Both treated samples were submitted to ultrasonic waves in the first stage. Bhat et al. (2011) reported that ultrasonic waves increased the total

Table 2. Water loss (WL) and solids gain (SG) after the osmotic process

\begin{tabular}{|c|c|c|c|c|c|}
\hline \multicolumn{4}{|c|}{ Osmotic dehydration } & WL & SG \\
\hline $\begin{array}{l}\text { Ultrasound frequency } \\
\text { at first stage (kHz) }\end{array}$ & $\begin{array}{l}\text { Ultrasound frequency } \\
\text { at second stage (kHz) }\end{array}$ & $\begin{array}{l}\text { Stevia-based solution concentration } \\
\text { at the second stage }\left(\mathrm{g} \mathrm{kg}^{-1}\right)\end{array}$ & $\begin{array}{l}\text { Sample immersion time } \\
\text { in the second stage (min) }\end{array}$ & \multicolumn{2}{|c|}{$(\%)$} \\
\hline \multirow[t]{6}{*}{$x^{2}$} & \multirow{6}{*}{ 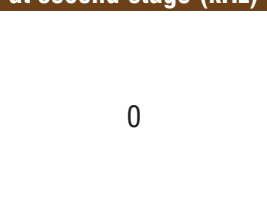 } & \multirow{3}{*}{ 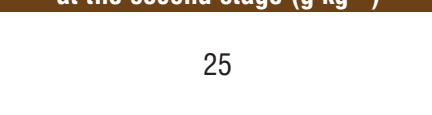 } & 10 & $1.94 \pm 0.11$ & $1.20 \pm 0.04$ \\
\hline & & & 20 & $1.02 \pm 0.00$ & $0.03 \pm 0.00$ \\
\hline & & & 30 & $0.61 \pm 0.16$ & $1.33 \pm 0.02$ \\
\hline & & \multirow{3}{*}{50} & 10 & $2.70 \pm 0.19$ & $-0.43 \pm 0.02$ \\
\hline & & & 20 & $3.87 \pm 0.68$ & $-0.09 \pm 0.09$ \\
\hline & & & 30 & $3.66 \pm 0.08$ & $2.00 \pm 0.01$ \\
\hline \multirow{6}{*}{0} & \multirow{6}{*}{25} & \multirow{3}{*}{25} & 10 & $0.47 \pm 0.00$ & $-1.9 \pm 0.00$ \\
\hline & & & 20 & $2.05 \pm 0.31$ & $-2.05 \pm 0.03$ \\
\hline & & & 30 & $3.84 \pm 0.00$ & $1.00 \pm 0.18$ \\
\hline & & \multirow{3}{*}{50} & 10 & $6.62 \pm 0.11$ & $1.73 \pm 0.02$ \\
\hline & & & 20 & $6.16 \pm 0.07$ & $1.73 \pm 0.01$ \\
\hline & & & 30 & $8.82 \pm 0.48$ & $2.10 \pm 0.08$ \\
\hline \multirow{6}{*}{25} & \multirow{6}{*}{0} & \multirow{3}{*}{25} & 10 & $2.68 \pm 0.30$ & $0.45 \pm 0.03$ \\
\hline & & & 20 & $5.15 \pm 0.20$ & $1.44 \pm 0.03$ \\
\hline & & & 30 & $4.78 \pm 0.30$ & $1.88 \pm 0.04$ \\
\hline & & \multirow{3}{*}{50} & 10 & $6.72 \pm 0.43$ & $0.73 \pm 0.05$ \\
\hline & & & 20 & $7.88 \pm 0.65$ & $3.18 \pm 0.10$ \\
\hline & & & 30 & $9.74 \pm 0.37$ & $3.56 \pm 0.06$ \\
\hline \multirow{6}{*}{25} & \multirow{6}{*}{25} & \multirow{3}{*}{25} & 10 & $4.83 \pm 0.31$ & $0.91 \pm 0.04$ \\
\hline & & & 20 & $4.96 \pm 0.21$ & $1.51 \pm 0.03$ \\
\hline & & & 30 & $7.10 \pm 0.07$ & $2.24 \pm 0.01$ \\
\hline & & \multirow{3}{*}{50} & 10 & $9.76 \pm 0.20$ & $1.97 \pm 0.03$ \\
\hline & & & 20 & $8.16 \pm 0.02$ & $2.33 \pm 0.00$ \\
\hline & & & 30 & $11.61 \pm 0.47$ & $2.99 \pm 0.08$ \\
\hline
\end{tabular}


Table 3. Quality parameters of fresh and processed mango

\begin{tabular}{|c|c|c|c|c|c|c|}
\hline \multirow{2}{*}{ Sample } & \multirow{2}{*}{$\begin{array}{l}\text { Total phenolics } \\
\text { (mg GAE g-1 DM) }\end{array}$} & \multirow{2}{*}{$\begin{array}{l}\text { Total carotenoids } \\
\left(\mu g g^{-1} D M\right)\end{array}$} & \multicolumn{4}{|c|}{ Color } \\
\hline & & & $\mathrm{L}^{*}$ & $a^{*}$ & $\mathbf{b}^{*}$ & TCD \\
\hline Fresh & $2.74 \pm 0.15 \mathrm{a}$ & $41.04 \pm 0.00 \mathrm{a}$ & $58.21 \pm 0.54 \mathrm{a}$ & $4.21 \pm 0.19 a$ & $54.36 \pm 0.39 a$ & - \\
\hline D3S 1 & $4.21 \pm 0.01 b$ & $20.59 \pm 0.29 b$ & $55.56 \pm 0.36 b$ & $2.93 \pm 0.23 b$ & $43.03 \pm 0.38 b$ & 11.71 \\
\hline D3S 2 & $4.08 \pm 0.10 b$ & $36.86 \pm 1.80 c$ & $57.33 \pm 0.88 a$ & $3.27 \pm 0.30 b$ & $48.88 \pm 1.22 c$ & 5.63 \\
\hline
\end{tabular}

Samples with the same letter within the same column showed no statistically significant difference for their mean values at 0.05 probability level; D3S 1 - Ultrasound in the first stage for 30 min followed by immersion of samples in a $500 \mathrm{~g} \mathrm{~kg}^{-1}$ Stevia-based solution for $30 \mathrm{~min}$ at $0 \mathrm{~Hz}$; D3S 2 - Ultrasound in the first stage for 30 min followed by the sample immersion in a 500 $\mathrm{g} \mathrm{kg}^{-1}$ Stevia-based solution for $30 \mathrm{~min}$ at $25 \mathrm{~Hz}$

phenolic content of Kasturi juice. This increase may be related to the pore formation in the vegetal tissue when ultrasonic waves are applied, improving the extraction of polyphenols during sample preparation, as reported by Gamboa-Santos et al. (2013). However, applying ultrasound again in the second stage (D3S 2 sample) did not result in increased TPC when compared to D3S 1 treated mango. It is possible that in this second stage a cell rupture surface caused by cavitation might contribute to the release of phenolics, as observed by Pingret et al. (2013).

Regarding total carotenoids content, the value for control untreated mango was $41.04 \mu \mathrm{g} \mathrm{g}^{-1} \mathrm{DM}$ and it exhibited significant change after the $\mathrm{D} 3 \mathrm{~S}$ process. Several investigations reported changes in carotenoid content during processing. It is known that carotenoids stability in foods is dependent on some factors, like the presence of light and their physical and chemical characteristics (Provesi et al., 2011).

Ashokkumar et al. (2008) observed that the level of hydroxylation in food could be improved by hydroxyl radicals generated when ultrasonic waves were applied. However, those radicals might affect the quality of some materials because of the antioxidant capacity reduction (São José et al., 2014). Rawson et al. (2011) observed that the hydroxyl radicals generated may result in the decomposition of lycopene, a lipophilic bioactive antioxidant in watermelon juice.

When ultrasonic waves were applied in both osmotic stages, the samples had higher carotenoid contents. This might have happened due to a more prolonged exposure to ultrasound and then the effect of cavitation produced by its application. In addition, the mechanical effect produced by ultrasonic waves permits a higher solvent penetration into the material, increasing the solute transfer rate from the food to the solvent (Zou et al., 2013).

Color parameters of mango are presented in Table 3. Significant differences can be observed between samples that were submitted to the D3S technique and the fresh ones (95\% confidence level). D3S treated mangoes have a significant reduction in $\mathrm{a}^{*}$ and $\mathrm{b}^{\star}$ values. In addition, lightness $\left(\mathrm{L}^{\star}\right)$ values also decreased and the fresh fruit presented a lighter color than the processed samples. Similar results were found by previous studies involving ultrasound, as the one reported by Fava et al. (2011), which submitted the grape berry to ultrasonic waves and observed differences in the color parameters.

The total color difference (TCD), calculated based on $L^{*}, a^{*}$ and $b^{*}$ values, is being used to determine the effect of processing on food color (Guiné \& Barroca, 2012). The smaller the value of TCD, the smaller is the deviation in color with respect to the reference (untreated sample). The TCD was lower when ultrasound was applied at both D3S stages, thus suggesting that it resulted in mango samples with fewer color changes when compared to the fresh fruit.
Choi et al. (2002) reported that a value for total color difference greater than 2 indicated appreciable differences in the visual impression of many products. Thus, in this study, the change in mangoes color after the process was visually observed.

Cavitation induced by ultrasound may lead to the differences in color, as reported by Sala et al. (1995) for sonicated tomato juice. These authors reported that cavitation is responsible for several reactions, like quicken chemical reaction, accelerate diffusion rates, among others. Mango pulp is rich in yellow-red colored components such as carotenoids (Kaushik et al., 2014) and the processing conditions can affect them. Hence, as the mangoes submitted to ultrasonic waves in both stages had greater total carotenoids content, those samples had the lower TCD value.

\section{Conclusions}

1. Submitting mango samples to ultrasonic waves in the D3S process first stage resulted in higher sugar removal.

2. The incorporation of natural sweetener (Stevia) was higher without application of ultrasound in the second stage of the D3S process.

3. Higher total phenolic content was obtained after using the D3S technique in mango samples.

4. Although total carotenoids content and color parameters values decreased with processing, smaller changes could be obtained when using ultrasonic waves in both D3S stages.

\section{ACKnowledgments}

The authors gratefully acknowledge CNPq (National Council for Scientific and Technological Development) and UFPE (Federal University of Pernambuco) for financial aid, and Steviafarma Industrial (Brazil) for the donation of the Stevia-based sweetener.

\section{Literature Cited}

Ashokkumar, M.; Sunartio, D.; Kentish, S.; Mawson, R.; Simons, L.; Vilkhu, K.; Versteeg, C. Modification of food ingredients by ultrasound to improve functionality: A preliminary study on a model system. Innovative Food Science and Emerging Technologies, v.9, p.155-160, 2008. https://doi.org/10.1016/j. ifset.2007.05.005

Azoubel, P. M.; Baima, M. do A. M.; Amorim, M. da R.; Oliveira, S. S. B. Effect of ultrasound on banana cv Pacovan drying kinetics. Journal of Food Engineering, v.97, p.194-198, 2010. https://doi. org/10.1016/j.jfoodeng.2009.10.009 
Bhat, R.; Kamaruddin, N. S. B. C.; Min-Tze, L.; Karim, A. A. Sonication improves kasturi lime (Citrus microcarpa) juice quality. Ultrasonics Sonochemistry, v.18, p.1295-1300, 2011. https://doi. org/10.1016/j.ultsonch.2011.04.002

Choi, M. H.; Kim, G. H.; Lee, H. S. Effects of ascorbic acid retention on juice colour and pigment stability in blood orange (Citrus sinensis) juice during refrigerated storage. Food Research International, v.35, p.753-759, 2002. https://doi.org/10.1016/ S0963-9969(02)00071-6

Crammer, B.; Ikan, R. Sweet glycosides from the Stevia plant. Chemistry in Britain, v.22, p.915-918, 1986.

Elkins, R. Stevia: Nature's sweetener. California: Woodland Publishing, 1997. $18 \mathrm{p}$.

Fava, J.; Hodara, K.; Nieto, A.; Guerrero, S.; Alzamora, S. M.; Castro, M. A. Structure (micro, ultra, nano), color and mechanical properties of Vitis labrusca L. (grape berry) fruits treated by hydrogen peroxide, UV-C irradiation and ultrasound. Food Research International, v.44, p.2938-2948, 2011. https://doi. org/10.1016/j.foodres.2011.06.053

Gamboa-Santos, J.; Soria, A. C.; Villamiel, M.; Montilla, A. Quality parameters in convective dehydrated carrots blanched by ultrasound and conventional treatment. Food Chemistry, v.141, p.616-624, 2013. https://doi.org/10.1016/j.foodchem.2013.03.028

Garcia-Noguera, J.; Weller, C. L.; Oliveira, F. I. P.; Rodrigues, S.; Fernandes, F. A. N. Dual-stage sugar substitution in strawberries with a Stevia-based sweetener. Innovative Food Science and Emerging Technologies, v.11, p.225-230, 2010. https://doi. org/10.1016/j.ifset.2009.07.001

Gasmalla, M. A. A.; Yang, R.; Hua, X. Stevia rebaudiana Bertoni: An alternative sugar replacer and its application in food industry. Food Engineering Reviews, v.6, p.150-162, 2014. https://doi. org/10.1007/s12393-014-9080-0

Guiné, R. P. F.; Barroca, M. J. Effect of drying treatments on texture and color of vegetables (pumpkin and green pepper). Food and Bioproducts Processing, v.90, p.58-63, 2012. https://doi. org/10.1016/j.fbp.2011.01.003

Kaushik, N.; Kaur, B. P.; Rao, P. S.; Mishra, H. N. Effect of high pressure processing on color, biochemical and microbiological characteristics of mango pulp (Mangifera indica cv. Amrapali). Innovative Food Science and Technologies, v.22, p.40-50, 2014. https://doi.org/10.1016/j.ifset.2013.12.011

Kroyer, G. Stevioside and Stevia-sweetener on food: Application, stability and interaction with food ingredients. Journal für Verbrauchershutz und Lebensmittelsicherheit, v.5, p.225-229, 2010. https://doi.org/10.1007/s00003-010-0557-3

Medeiros, R. A. B. de; Barros, Z. M. P.; Carvalho, C. B. O. de; Fraga Neta, E. G.; Maciel, M. I. S.; Azoubel, P. M. Influence of dual-stage sugar substitution pretreatment on drying kinetics and quality parameters of mango. LWT - Food Science and Technology, v.67, p.167-173, 2016. https://doi.org/10.1016/j.lwt.2015.11.049
Mendes, G. R. L.; Freitas, C. H. de; Scaglioni, P. T.; Schimidt, C. G.; Furlong, E. B. Condições para desidratação osmótica de laranjas e as propriedades funcionais do produto. Revista Brasileira de Engenharia Agrícola e Ambiental, v.17, p.1210-1216, 2013. https:// doi.org/10.1590/S1415-43662013001100012

Oliveira, F. I. P.; Rodrigues, S.; Fernandes, F. A. N. Production of low calories Malay apples by dual-stage sugar substitution with Stevia-based sweetener. Food and Bioproducts Processing, v.90, p.713-718, 2012. https://doi.org/10.1016/j.fbp.2012.02.002

Pingret, D.; Fabiano-Tixier, A. S.; Chemat, F. Degradation during application of ultrasound in food processing: A review. Food Control, v.31, p.593-606, 2013. https://doi.org/10.1016/j. foodcont.2012.11.039

Prakash, I.; Upreti, M.; Dubois, G.; King, G.; Klucik, J.; San Miguel, R. Sweetness enhancers, sweetness enhanced sweetener compositions, methods for their formulation, and use. Atlanta: Patent Cooperation Treaty, 2008. 121p.

Provesi, J. G.; Dias, C. O.; Amante, E. R. Changes in carotenoids during processing and storage of pumpkin puree. Food Chemistry, v.128, p.195-202, 2011. https://doi.org/10.1016/j.foodchem.2011.03.027

Pu, Y. Y.; Sun, D. W. Prediction of moisture content uniformity of microwave-vacuum dried mangoes as affected by different shapes using NIR hyperspectral imaging. Innovative Food Science and Emerging Technologies, v.33, p.348-356, 2016. https://doi. org/10.1016/j.ifset.2015.11.003

Rawson, A.; Patras, A.; Tiwari, B. K.; Noci, F.; Koutchma, T.; Brunton, $\mathrm{N}$. Effect of thermal and nonthermal processing technologies on the bioactive content of exotic fruits and their products: Review of recent advances. Food Research International, v.44, p.1875-1887, 2011. https://doi.org/10.1016/j.foodres.2011.02.053

Rodriguez-Amaya, D. B. A guide to carotenoid analysis in foods. Washington: International Life Science Institute Press, 1999. 64p.

Sala, F. J.; Burgos, J.; Condón, S.; Lopez, P.; Raso, J. Effect of heat and ultrasound on microorganisms and enzymes. In: Gould, G. W. (ed.). New methods of food preservation. London: Blackie Academic \& Professional, 1995. Cap.9, p.177-204.

São José, J. F. B.; Andrade, N. J.; Ramos, A. M.; Vanetti, M. C. D.; Stringheta, P. C.; Chaves, J. B. P. Decontamination by ultrasound application in fresh fruits and vegetables. Food Control, v.45, p.36-50, 2014. https://doi.org/10.1016/j.foodcont.2014.04.015

Singleton, V. L.; Orthofer, R.; Lamuela, R. M. Analysis of total phenols and other oxidation substrates and antioxidants by means of FolinCiocalteau reagent. Methods in Enzymology, v.299, p.152-178, 1999. https://doi.org/10.1016/S0076-6879(99)99017-1

Sogi, D. S.; Siddiq, M.; Dolan, K. D. Total phenolics, carotenoids and antioxidant properties of Tommy Atkins mango cubes as affected by drying techniques. LWT - Food Science and Technology, v.62, p.564-568, 2015. https://doi.org/10.1016/j.lwt.2014.04.015

Zou, T. B.; Jia, Q.; Li, H. W.; Wang, C. X.; Wu, H. F. Response surface methodology for ultrasound-assisted extraction of astaxanthin from Haematococcus pluvialis. Marine Drugs, v.11, p.1644-1655, 2013. https://doi.org/10.3390/md11051644 